\title{
KUALITAS PENGERINGAN KAYU MAHONI PADA BERBAGAI VARIASI KERAPATAN INCISING DENGAN DUA SKEDUL PENGERINGAN SUHU TINGGI
}

\section{TOMY LISTYANTO*, FADLUL RAHMAN, \& HYANA SWARGARINI}

\author{
Departemen Teknologi Hasil Hutan, Fakultas Kehutanan, Universitas Gadjah Mada, \\ Jl. Agro No. 1, Bulaksumur, Sleman, 55281 \\ *Email: tomy.listyanto@gadjahmada.edu
}

\begin{abstract}
The aims of this research were to investigate the effects of interaction between incising densities and two drying schedules on drying rate and defects as well as to examine the effect of incising densities on static bending characteristics of dried mahogany. Tree mahogany (Swietenia mahogany) trees with the diameter of 300-350 $\mathrm{mm}$ were cut and sawn into columns with the dimension of $60 \mathrm{~mm} \times 100 \mathrm{~mm} \times 500 \mathrm{~mm}$. Each column was cut into five parts with the length of $500 \mathrm{~mm}$. A small sample with the dimension of $20 \mathrm{~mm} \times 20 \mathrm{~mm} \times 25$ $\mathrm{mm}$ were taken in between drying sample to measure moisture content. Five incising densities, which were 0 holes $/ \mathrm{m}^{2}$ (unincised), 1000 holes $/ \mathrm{m}^{2}, 2000$ holes $/ \mathrm{m}^{2}, 3000$ holes $/ \mathrm{m}^{2}$ and holes $/ \mathrm{m}^{2}$, were applied to the drying sample. Samples were dried with two different drying schedules until the moisture content of $12 \%$. Drying rate, defects, and moisture distribution were measured to evaluate the drying quality. Static bending test was applied to examine the strength properties. The results showed that incising densities of 3000-4000 holes $/ \mathrm{m}^{2}$ could significantly improve drying rate and final moisture content distribution. There was no significants defects due to the variation of incising densities and drying schedules. No significant decrease of modulus of elasticity and modulus of rupture among five incising densities was found in this research.
\end{abstract}

Keywords: incising, high-temperature-drying, mahogany, static bending, drying schedule.

\section{INTISARI}

Tujuan dari penelitian ini adalah untuk mengetahui pengaruh interaksi variasi kerapatan incising dan dua skedul pengeringan terhadap kecepatan dan cacat-cacat pengeringan kayu mahoni, serta mengetahui pengaruh variasi kerapatan incising terhadap kekuatan lengkung statik kayu mahoni yang telah dikeringkan. Tiga pohon mahoni (Swietenia mahagony) berdiameter 300-350 mm ditebang dan selanjutnya dibelah dan dibuat menjadi balok dengan ukuran $60 \mathrm{~mm} \times 100 \mathrm{~mm}$ dengan panjang $500 \mathrm{~mm}$ untuk dijadikan sampel pengeringan. Di antara masing-masing bagian tersebut, dibuat sampel ukuran $20 \mathrm{~mm} \times 20 \mathrm{~mm} \times 25 \mathrm{~mm}$, yang digunakan untuk penentu kadar air awal dan distribusinya. Sampel pengeringan selanjutnya dibagi menjadi 5 variasi kerapatan incising, yaitu 0 lubang $/ \mathrm{m}^{2}$ (tanpa incising), 1000 lubang $/ \mathrm{m}^{2}, 2000 \mathrm{lubang} / \mathrm{m}^{2}, 3000$ lubang $/ \mathrm{m}^{2}$, dan 4000 lubang $/ \mathrm{m}^{2}$. Setiap variasi kerapatan incising selanjutnya akan dikeringkan dengan 2 skedul pengeringan, yaitu suhu pengeringan $100^{\circ} \mathrm{C}$ sampai tercapai kadar air akhir $12 \%$ dan suhu $60^{\circ} \mathrm{C}$ pada 8 jam pertama dan selanjutnya dilanjutkan $100^{\circ} \mathrm{C}$, sampai tercapai kadar air akhir $12 \%$. Paramater yang diamati adalah kecepatan pengeringan, cacat retak permukaan, dan distribusi kadar air akhir. Hasil analisis menunjukkan bahwa kerapatan incising 3000-4000 lubang $/ \mathrm{m}^{2}$ memberikan pengaruh yang cukup nyata di dalam mempercepat proses pengeringan dan distribusi kadar air akhir. Skedul pengeringan dan variasi kerapatan incising tidak berpengaruh pada retak permukaan. Pra perlakuan incising sampai batas 4000 lubang $/ m^{2}$ ini dapat diterapkan untuk mempercepat proses pengeringan dengan penurunan nilai modulus elastisitas dan modulus patah yang tidak berbeda nyata.

Kata kunci: incising, pengeringan suhu tinggi, mahoni, mahoni, lengkung statik, skedul pengeringan. 


\section{PENDAHULUAN}

Berbagai macam penelitian dilakukan untuk mempercepat proses pengeringan dan juga meminimalisir cacat-cacat yang terjadi selama proses pengeringan berlangsung. Salah satu upaya untuk mempercepat pengeringan adalah membuat lubang incising, yaitu sebuah proses pelubangan pada kayu dengan diameter yang cukup kecil dengan arah tegak lurus arah serat kayu. Konsepnya adalah daerah lubang incising yang tegak lurus arah serat kayu akan menciptakan permukaan buatan/imaginer (imaginary surfaces), dimana air di dalam kayu akan bergerak lebih cepat ke area tersebut dibandingkan bergerak keluar melalui permukaan kayu yang sebenarnya (Simpson, 1987; Hattori et al., 1997; Listyanto et al., 2013). Dengan adanya permukaan imaginer tersebut maka akan memperpendek waktu yang dibutuhkan air di bagian dalam kayu untuk keluar. Penggunaan laser incising dengan kerapatan 2500 lubang $/ \mathrm{m}^{2}$ pada kayu sugi (Cryptomeria japonica $\mathrm{D}$. Don) dengan menggunakan pengeringan mikrowave dan steam injection telah berhasil mempercepat proses pengeringan hingga mencapai 5 kali lipat dibandingkan dengan proses-proses pengeringan terbaru yang lainnya (Hattori et al., 1997; Listyanto et al., 2013). Namun demikian, investasi alat/mesin laser terhitung cukup mahal untuk negara-negara berkembang seperti Indonesia. Oleh karena itu perlu diupayakan pembuatan incising dengan mekanisme dan alat yang lebih murah.

Pembuatan lubang incising yang relatif murah antara lain dengan menggunakan sistem bor (drilling). Sistem bor ini relatif mudah dilakukan dengan biaya investasi yang relatif terjangkau. Oleh karena itu, penggunaan sistem bor ini perlu diteliti dan diuji apakah proses incising dengan bor juga mampu mempercepat proses pengeringan dan mengurangi cacat-cacat yang terjadi. Semakin rapat lubang incising maka akan memberikan lebih banyak jalan masuknya sumber panas dan juga tempat keluarnya air dari dari dalam kayu. Namun demikian, penelitian tersebut perlu diuji dengan tingkat kerapatan yang berbeda. Salah satu jenis kayu paling komersial di Jawa setelah kayu jati adalah jenis mahoni. Kayu mahoni banyak digunakan dalam pembuatan konstruksi ringan, mebel, dan kerajinan. Mahoni banyak diminati karena memiliki tekstur dan warna yang menarik (Palmer, 1994) memiliki kelas kuat II-III (Martawijaya et al., 2005).

Usaha untuk mempercepat proses pengeringan selain dengan perlakuan incising/pelubangan adalah dengan penerapan suhu tinggi. Pengeringan suhu tinggi dapat didefinisikan sebagai pengeringan dengan kondisi suhu sama atau lebih tinggi dari $100^{\circ} \mathrm{C}$ (Obataya et al., 2006). Penggunaan suhu tinggi mampu meningkatkan tingkat difusi (Siau, 1984) yang akan meningkatkan pengeluaran air dari dalam kayu. Kemampuan penggunaan suhu tinggi ini dalam mempercepat proses pengeringan didukung oleh beberapa hasil penelitian (Kollmann, 1961; Cech dan Huffman, 1971; Huffman, 1972; Rhatigan et al., 2003). Suhu yang tinggi, khususnya yang mencapai diatas titik didih air, akan membentuk uap yang mampu untuk mempercepat pergerakan air sepanjang serat (Stamm dan Raleigh, 1967; Skaar, 1988). Menurut Pandey dan Brown (2000) ketika kayu dikeringkan dengan suhu tinggi, maka lignin yang secara natural mengikat serat, dilenturkan dan menjadikan serat netral atau tidak tertekan. Lignin kemudian mengeras kembali dan kayu tidak tertekan sehingga menyebabkan cacat yang terjadi menjadi minimal. Namun demikian, tanpa bantuan perlakuan lain, penggunaan suhu tinggi juga berpotensi menyebabkan kayu mudah retak dan pecah karena adanya perbedaan distribusi kadar air yang cukup tajam dari permukaan ke bagian dalam kayu (Rose et 
al., 1983). Hal yang perlu dipertimbangkan juga adalah sejauh mana suhu yang digunakan akan mempengaruhi penurunan sifat mekanika kayu tersebut (Gerhards, 1979; Sehlstedt-Persson, 1995; Fruhwald, 2007). Oleh karena itu perlu dilakukan penelitian sejauh mana pengeringan suhu tinggi dapat diterapkan pada jenis-jenis kayu komersial di Indonesia. Penggunaan suhu tinggi pada kayu yang diberi perlakuan incising dapat meningkatkan kecepatan pengeringan yang tinggi dibanding dengan suhu rendah (Hattori et al., 1997).

Tujuan dari penelitian ini adalah untuk mengetahui pengaruh interaksi variasi kerapatan incising dan dua skedul pengeringan suhu tinggi terhadap kecepatan dan cacat-cacat pengeringan kayu mahoni dan mengetahui pengaruh variasi kerapatan incising terhadap kekuatan lengkung statik kayu mahoni yang telah dikeringkan. Paramater yang diamati antara lain kecepatan pengeringan, distribusi kadar air akhir, dan cacat retak. Sifat mekanika kayu juga perlu dilakukan pengujian untuk mengetahui pengaruh variasi kerapatan incising dan metode pengeringan terhadap kekuatan lengkung statik kayu. Manfaat dari penelitian ini adalah untuk mendapatkan informasi dasar tentang pengaruh lubang incising dengan menggunakan bor terhadap kemungkinannya sebagai perlakuan awal untuk mempercepat proses pengeringan kayu secara umum. Dengan adanya informasi yang diharapkan tersebut, maka dapat dilakukan penelitian-penelitian selanjutnya dengan berbagai metode pengeringan dan variasi jenis kayu yang berbeda.

\section{BAHAN DAN METODE}

Bahan untuk penelitian ini adalah 3 pohon mahoni (Switenia mahagony) berdiameter 300-350 $\mathrm{mm}$. Setelah ditebang, pohon mahoni dipotong menjadi beberapa log yang selanjutnya dibelah dan dibuat menjadi papan dengan ukuran $60 \mathrm{~mm} \times 120$ $\mathrm{mm}$ dengan panjang $2.800 \mathrm{~mm}$. Setiap papan selanjutnya dibagi menjadi 5 bagian dengan panjang $500 \mathrm{~mm}$ untuk dijadikan sampel pengeringan. Pada kedua ujung batang selanjutnya ditutup dengan lilin untuk menghindari berkurangnya air secara cepat dari ujung batang. Di antara masing-masing bagian tersebut, dibuat irisan dengan panjang $25 \mathrm{~mm}$. Selanjutnya irisan ini dibagi menjadi sampel ukuran

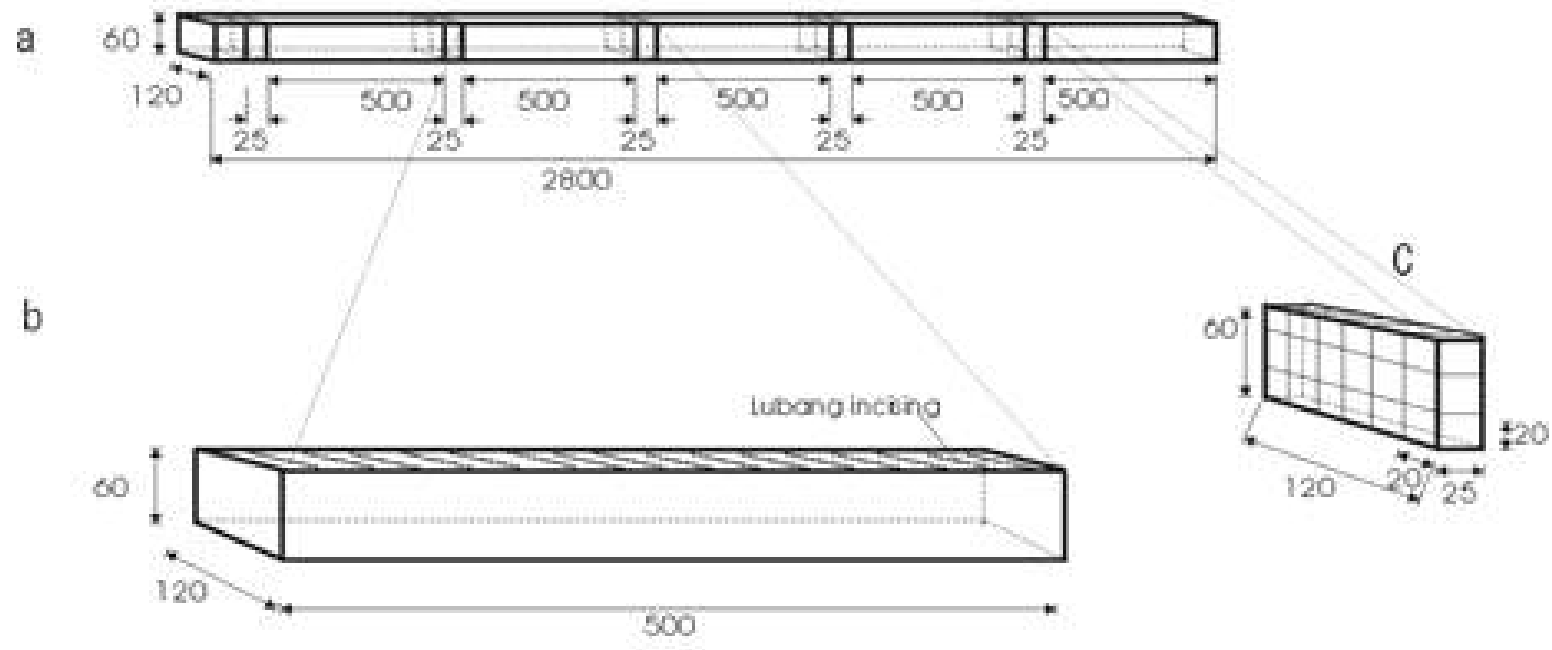

\section{Unit : $m m$}

Gambar 1. Sketsa pembuatan sampel pengeringan dan kadar air. Catatan: a. Cara pembagian sampel uji pengeringan. $b$. sampel uji pengeringan. c. sampel uji kadar air awal. 
$20 \mathrm{~mm} \times 20 \mathrm{~mm} \times 25 \mathrm{~mm}$, yang digunakan untuk penentu kadar air awal dan distribusinya. Detail pembagian batang dan sampel kadar air dapat dilihat pada Gambar 1. Jumlah ulangan untuk masingmasing perlakuan adalah 5 buah sampel.

Sampel pengeringan selanjutnya dibagi menjadi 5 variasi kerapatan incising, yaitu 0 lubang $/ \mathrm{m}^{2}$ (tanpa incising), 1000 lubang $/ \mathrm{m}^{2}, 2000$ lubang $/ \mathrm{m}^{2}, 3000$ lubang $/ \mathrm{m}^{2}$, dan 4000 lubang $/ \mathrm{m}^{2}$. Pembuatan incising dilakukan dengan mengacu pada pola yang diterapkan Listyanto et al. (2013) seperti pada Gambar 2. Diameter lubang diusahakan sebesar $3 \mathrm{~mm}$ menembus dari permukaan atas ke permukaan bawah. Jarak antar lubang incising dibuat seperti pada Tabel 1.

Setiap variasi kerapatan incising selanjutnya akan dikeringkan dengan 2 skedul pengeringan suhu tinggi. Skedul pertama adalah pengeringan dengan menggunakan suhu tinggi yaitu $100^{\circ} \mathrm{C}$ sampai tercapai kadar air akhir 12\%. Skedul pengeringan kedua dilakukan dengan mengeringkan sampel pada suhu $60^{\circ} \mathrm{C}$ selama 8 jam pertama dan dilanjutkan dengan suhu tinggi yaitu $100^{\circ} \mathrm{C}$ sampai tercapai kadar air akhir 12\%. Sampel kayu yang telah dikeringkan selanjutnya diamati kecepatan pengeringannya, cacat retak permukaan, dan distribusi kadar air akhir. Pembuatan sampel distribusi kadar air akhir mengacu pada Gambar 3.

Pengamatan kekuatan lengkung statik juga dilakukan pada sampel yang sudah kering (kadar air berkisar 12\%) mengacu pada British Standard Methods (BS373 1957). Contoh uji yang digunakan dalam penelitian ini adalah $20 \mathrm{~mm} \times 20 \mathrm{~mm} \times 300$ $\mathrm{mm}$ yang diambil dari bagian tengah masing-masing sampel yang dikeringkan (Gambar 3).

Analisis varian dilakukan untuk mengetahui pengaruh variasi kerapatan lubang incising dan skedul pengeringan yang diterapkan terhadap parameter pengamatan. Taraf signifikansi yang digunakan adalah $0,05 \quad(\alpha=0,05)$. Jika terjadi perbedaan signifikan pada pengaruh kerapatan

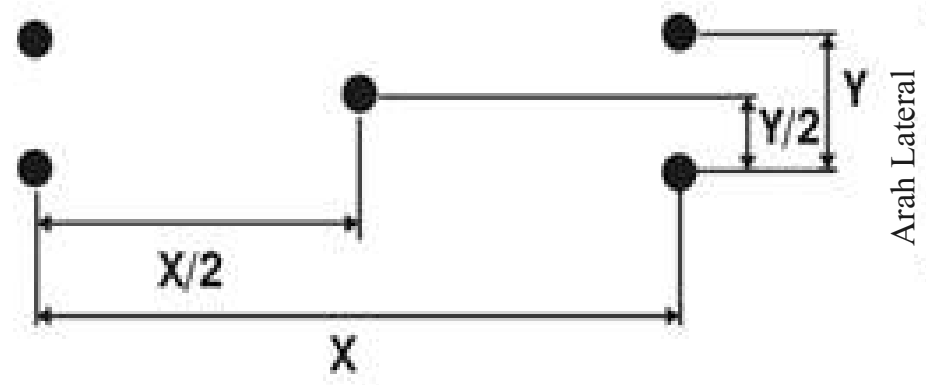

Arah Longitudinal

Gambar 2. Pola pembuatan lubang incising. Bulatan hitam menunjukkan posisi masing-masing lubang. Arah longitudinal merupakan arah panjang kayu, sedangkan arah lateral adalah arah lebar kayu.

Tabel 1. Penentuan jarak antar lubang incising berdasarkan kerapatannya.

\begin{tabular}{ccc}
\hline Kerapatan incising (lubang/m ) & $\mathrm{X}(\mathrm{mm})$ & $\mathrm{Y}(\mathrm{mm})$ \\
\hline 1000 & 113,5 & 15,8 \\
2000 & 29,4 & 11,3 \\
3000 & 73 & 9,1 \\
4000 & 63,2 & 7,9 \\
\hline
\end{tabular}

lubang incising, selanjutnya dilakukan uji lanjut dengan uji Tukey HSD. Analisis statistik dilakukan menggunakan Program SPSS for Windows Ver 16. 
a

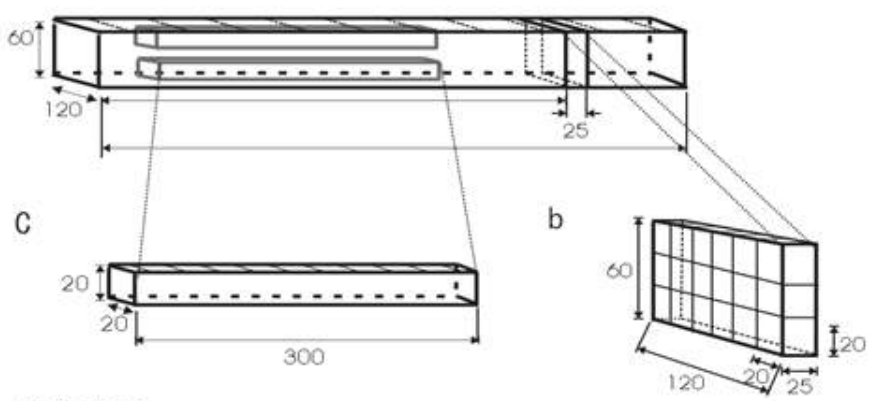

Unit : $\mathrm{mm}$

Gambar 3. Sketsa pembuatan sampel pengamatan setelah pengeringan.

Catatan: a. Sampel pengamatan setelah pengeringan. b. sampel

distribusi kadar air. c. sampel kekuatan lengkung statik.

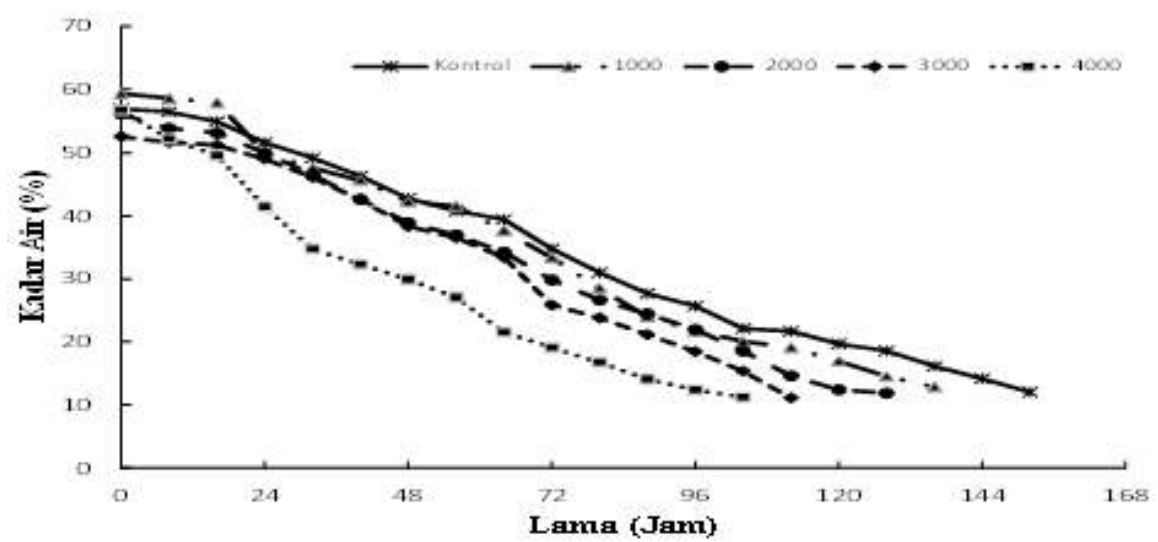

Gambar 4. Kecepatan pengeringan kayu mahoni pada berbagai variasi kerapatanincising.

\section{HASIL DAN PEMBAHASAN}

\section{Kecepatan Pengeringan}

Proses pengeringan ini dimulai dari kadar air awal $50-60 \%$ sampai kadar air tertuju yaitu 12\%. Hasil penelitian menunjukkan bahwa lama pengeringan bervariasi antara 96-160 jam. Proses lama penurunan kadar air kayu mahoni pada berbagai variasi kerapatan incising dapat dilihat pada Gambar 4. Hasil analisis varian (anova) menunjukkan bahwa variasi kerapatan incising berpengaruh nyata $(\mathrm{P}<0,05)$ terhadap kecepatan pengeringan sedangkan variasi skedul pengeringan tidak berpengaruh nyata terhadap kecepatan pengeringan. Setelah uji lanjut dengan uji Tukey HSD, didapatkan kecepatan pengeringan kayu mahoni dengan kerapatan incising
3000-4000 lubang $/ \mathrm{m}^{2}$ berbeda nyata $(\mathrm{P}<0,05)$ kecepatannya dibandingkan dengan kecepatan pengeringan kayu mahoni tanpa perlakuan incising (kontrol). Kecepatan pengeringan kayu mahoni dengan kerapatan incising 3000 dan 4000 lubang $/ \mathrm{m}^{2}$ sebesar 9,66\%/hari dan 10,6\%/hari. Hasil lengkap rerata kecepatan pengeringan dan hasil uji lanjut Tukey HSD dapat dilihat pada Gambar 5. Adanya lubang jumlah incising sebanyak 3000 lubang $/ \mathrm{m}^{2}$ menunjukkan mampu meningkatkan kecepatan pengeringan secara signifikan dibandingkan dengan kontrol (tanpa incising). Hal ini sesuai dengan penelitian sebelumnya yang menyatakan bahwa lubang incising membantu dalam hal memanaskan bagian dalam kayu secara lebih cepat dan juga membantu memberi jalan terhadap air di dalam kayu 


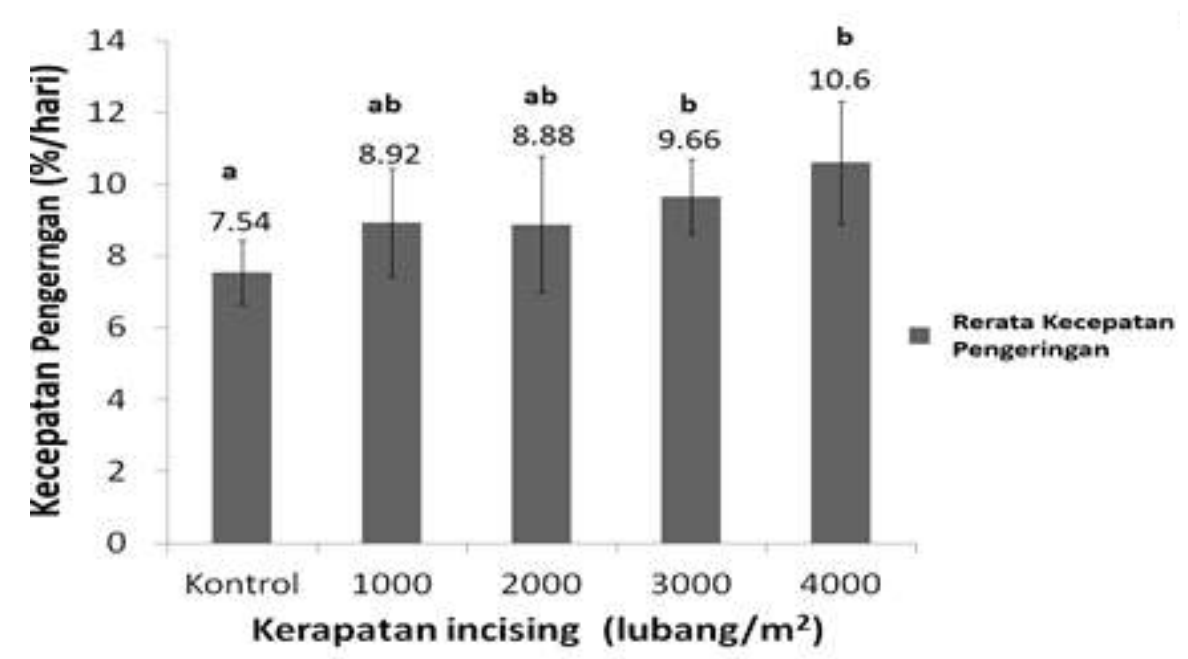

Gambar 5. Rerata kecepatan pengeringan kayu mahoni pada berbagai variasi kerapatan incising. Huruf a,b di atas bar menunjukkan hasil uji lanjut Tukey HSD, dimana huruf yang berbeda menunjukkan nilai kecepatan pengeringan yang berbeda nyata $(\mathrm{P}<0,05)$.

yang bergerak lebih cepat ke area tersebut dibandingkan bergerak keluar melalui permukaan kayu yang sebenarnya (Chudnoff, 1972; Simpson, 1987; dan Listyanto et al., 2013).

Berdasarkan hasil anova tersebut diatas maka didapatkan bahwa penerapan pengeringan dengan skedul suhu $100^{\circ} \mathrm{C}$ langsung ataupun dengan pemanasan awal suhu $60^{\circ} \mathrm{C}$ selama 8 jam dilanjutkan suhu $100^{\circ} \mathrm{C}$ menunjukkan perbedaan yang tidak nyata $(P>0,05)$. Selama ini, industri di Indonesia mengeringkan mahoni dengan suhu rendah menuju ke tinggi. Martawijaya et al. (2005) menyarankan menggunakan skedul pengeringan dengan suhu pengeringan $43-76^{\circ} \mathrm{C}$ dengan kelembaban relatif 75-33\%. Hasil observasi langsung di industri pengolahan kayu, pengeringan dengan mengacu skedul yang dijelaskan oleh Martawijaya et al. (2005) dengan ketebalan 40-60 mm umumnya membutuhkan lama 30-35 hari. Perlakuan suhu tinggi pada proses pengeringan ini menunjukkan hasil yang cukup cepat terhadap proses pengeringan kayu mahoni. Hal ini dimungkinkan karena suhu tinggi terjadi peningkatan permeabilitas pada kayu (Rhatigan et al., 2003) atau mampu meningkatkan tingkat difusi (Siau, 1984). Dengan demikian, secara umum penggunaan incising dan suhu tinggi dapat dipertimbangkan untuk mempercepat proses pengeringan kayu mahoni dengan dimensi yang besar. Melihat kecenderungan kenaikan kerapatan incising akan lebih mempercepat proses pengeringan maka perlu diuji penggunaan kerapatan yang lebih tinggi.

\section{Retak Permukaan}

Retak permukaan pada proses pengeringan ini bervariasi dari 1-100 mm. Rekapitulasi jumlah cacat retak dapat dilihat pada Gambar 6. Jumlah retak ini relatif kecil, umumnya retak permukaan yang tidak parah akan merapat kembali beberapa saat setelah proses pengeringan selesai. Lee et al. (2010) menjelaskan bahwa penggunaan suhu tinggi memungkinkan terjadinya pengurangan retak pada saat proses pengeringan. Dijelaskan oleh Pandey dan Brown (2000) bahwa ketika kayu dikeringkan dengan suhu tinggi, terjadi proses dimana lignin, yang secara natural mengikat serat, dilenturkan dan menjadikan serat netral atau tidak tertekan, yang mengakibatkan terjadinya penurunan kemungkinan terjadinya retak. 
Hasil anova menunjukkan bahwa skedul dengan proses pemanasan awal dan kerapatan incising tidak berpengaruh secara nyata terhadap total panjang retak permukaan. Ditinjau dari skedul pengeringan, hasil analisis menunjukkan bahwa dua skedul pengeringan suhu tinggi tidak memberikan pengaruh yang nyata $(\mathrm{P}>0,05)$ pada kemunculan terjadinya retak. Hal ini dapat diartikan bahwa pemanasan awal dengan suhu $60^{\circ} \mathrm{C}$ selama 8 jam tidak memberikan pengaruh terhadap jumlah retak dibandingkan dengan penggunaan suhu langsung $100^{\circ} \mathrm{C}$. Mempertimbangkan pengaruh incising, adanya lubang incising pada kerapatan tertentu juga belum mampu memberikan penurunan yang cukup nyata terhadap jumlah retak permukaan. Hal ini dimungkinkan karena dua hal. Pertama, cacat yang terjadi relatif kecil, baik yang pada kontrol maupun pada sampel yang diberi perlakuan incising, sehingga perbedaan yang disebabkan karena lubang incising menjadi tidak nyata. Kedua, adanya tingkat gradien kadar air akhir, walaupun sudah mengalami penurunan, tetapi antara di permukaan dan di bagian dalam masih relatif masih agak curam. Tingkat gradien kadar air yang curam antar permukaan dan bagian dalam merupakan salah satu penyebab terjadinya retak (Siau, 1984).

\section{Distribusi Kadar Air Akhir}

Distribusi kadar air akhir pada berbagai variasi kerapatan incising dapat dilihat pada Gambar 7. Berdasarkan gambar tersebut mengindikasikan bahwa kerapatan incising yang lebih tinggi berpotensi menurunkan tingkat gradien distribusi kadar air akhir sampel yang telah dikeringkan. Adanya penurunan gradien distribusi kadar air akhir berpengaruh di dalam mengurangi potensi cacat kayu termasuk retak (Langrish dan Walker, 2006). Hal ini menunjukkan bahwa lubang incising mampu memberikan jalan kepada udara panas untuk masuk dan memberikan jalan keluar air yang keluar dari dalam kayu. Hasil penelitian Dedic dan Zlatanovic (2001) dan Listyanto et al. (2013) menunjukkan bahwa jumlah cacat yang terjadi pada kayu sugi dengan kerapatan incising 2500 lubang $/ \mathrm{m}^{2}$ menurun secara signifikan. Hal ini disebabkan gaya tarik-menarik antar serat pada bagian permukaan dan bagian dalam menjadi tidak terlalu besar. Namun demikian, pada penelitian ini, penurunan gradien distribusi kadar

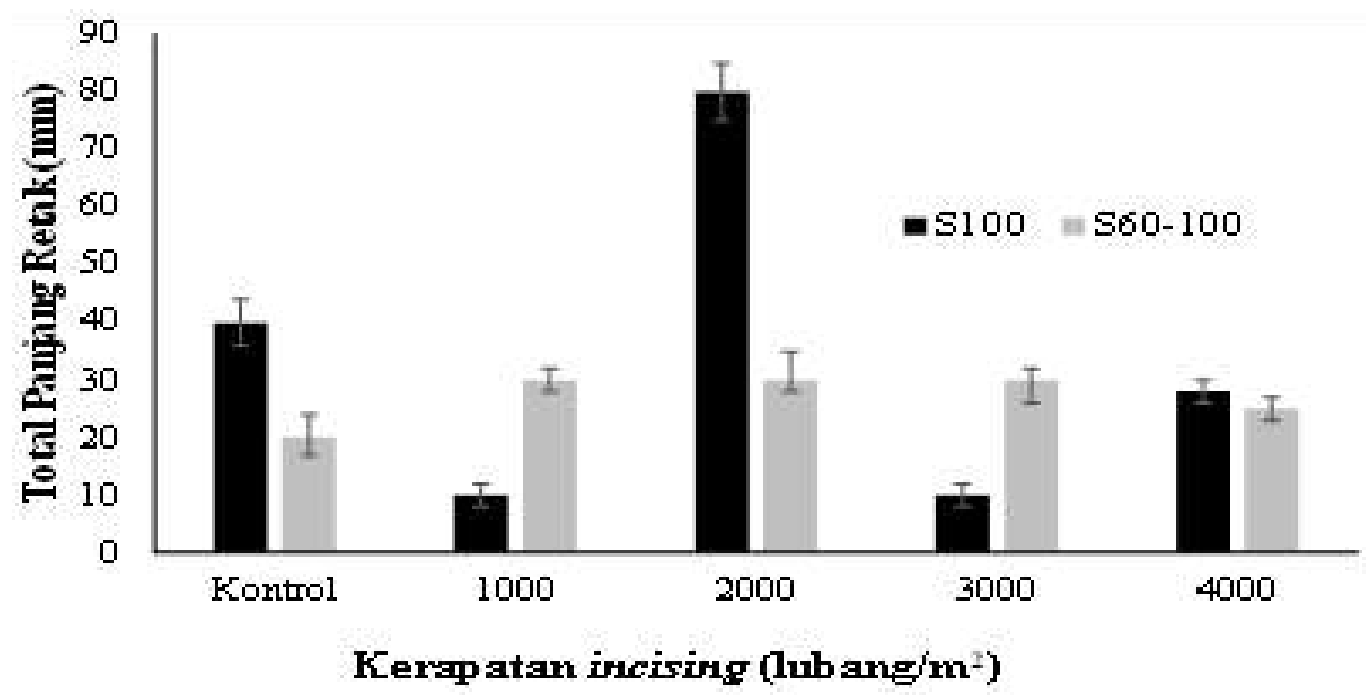

Gambar 6. Total retak permukaan kayu mahoni yang keringkan dengan dua skedul pengeringan dan lima variasi kerapatan incising. 


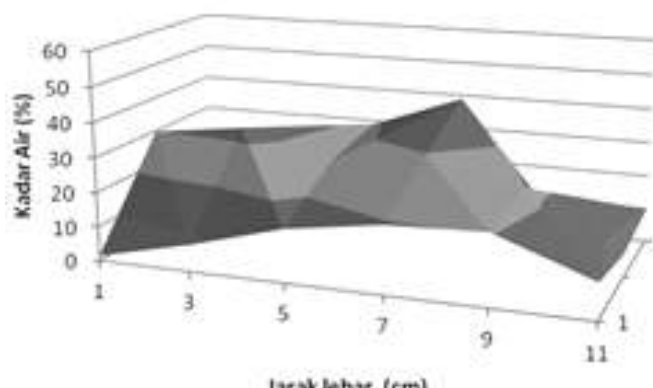

a)

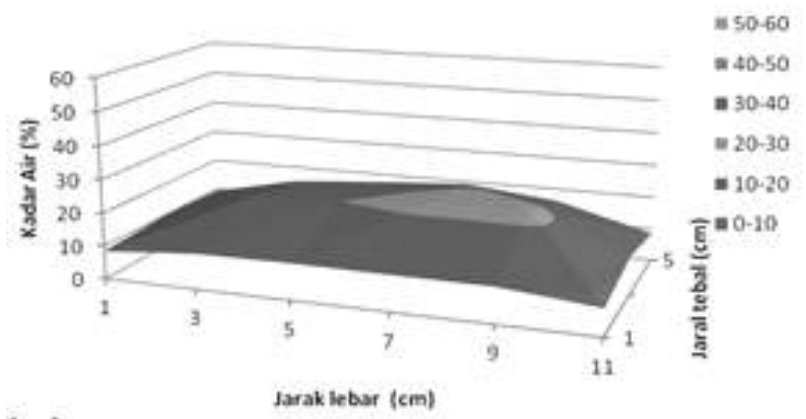

(c)

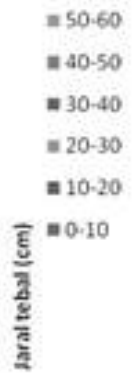

(b)

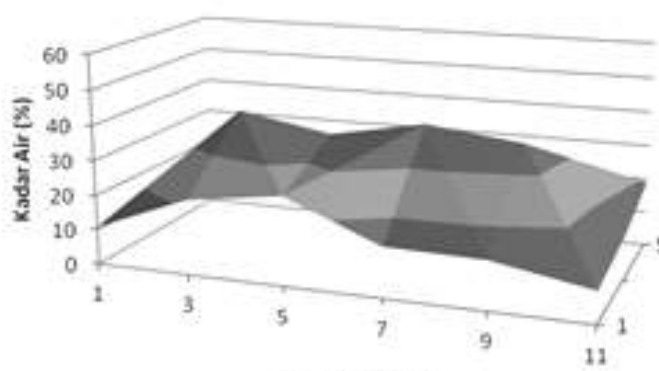

Jarak lebar (cm)

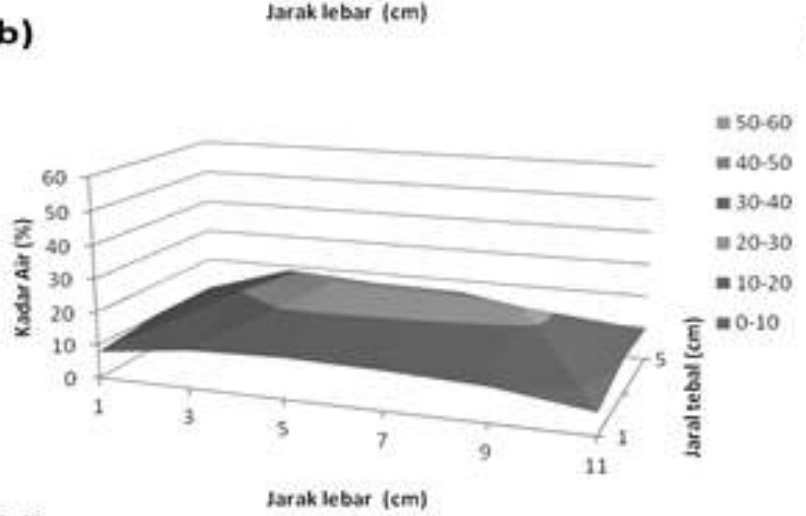

(d)

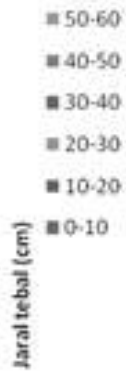

Gambar 7. Gradasi distribusi kadar air akhir pada kayu mahoni dengan variasi kerapatan incising.

Keterangan: a. Sampel control. b. Sampel dengan kerapatan incising 1000 lubang $/ \mathrm{m}^{2}$. c. Sampel dengan kerapatan incising 3000 lubang $/ \mathrm{m}^{2}$. d. Sampel dengan kerapatan incising 4000 lubang $/ \mathrm{m}^{2}$.

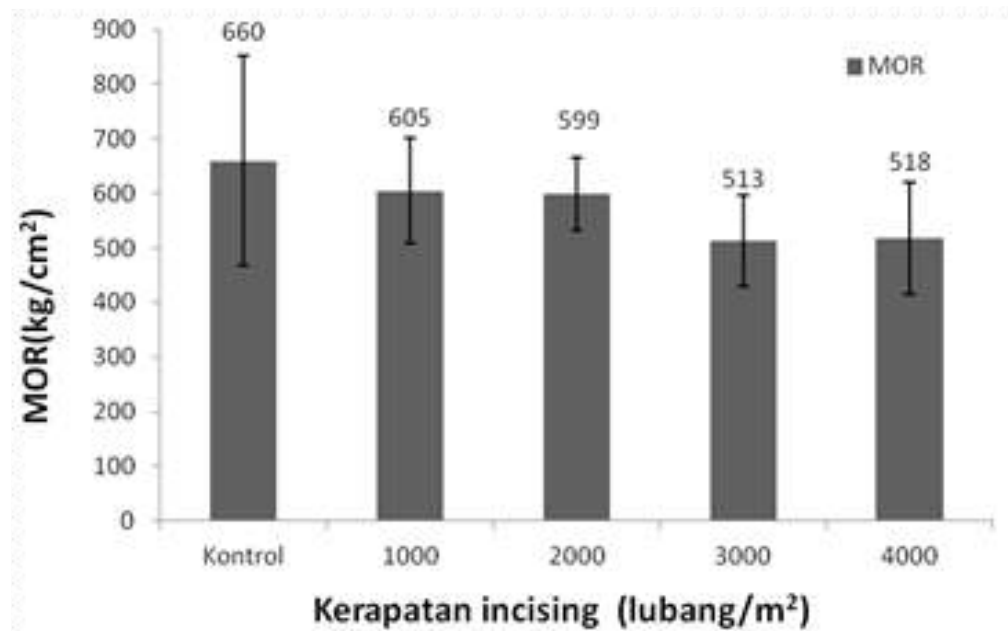

Gambar 8. Nilai modulus patah (MoR) kayu mahoni pada berbaga variasi kerapatan incising.

akhir belum mampu secara signifikan menurunkan jumlah retak permukaan.

\section{Keteguhan Lengkung Statik}

Untuk mengetahui kekuatan mekanika kayu yang mendapatkan perlakuan incising maka perlu dilakukan uji mekanika, salah satunya yang penting adalah keteguhan lengkung statik. Uji keteguhan lengkung statik meliputi modulus elastis (MoE) dan modulus patah (MoR). Nilai rerata MoR dan MoE dapat dilihat pada Gambar 8 dan 9. Hasil MoR tidak berbeda data menurut Martawijaya et al. (2005) dimana kayu mahoni memiliki MoR sebesar 623 $\mathrm{kg} / \mathrm{cm}^{2}$, namun nilai MoE di bawah data menurut 


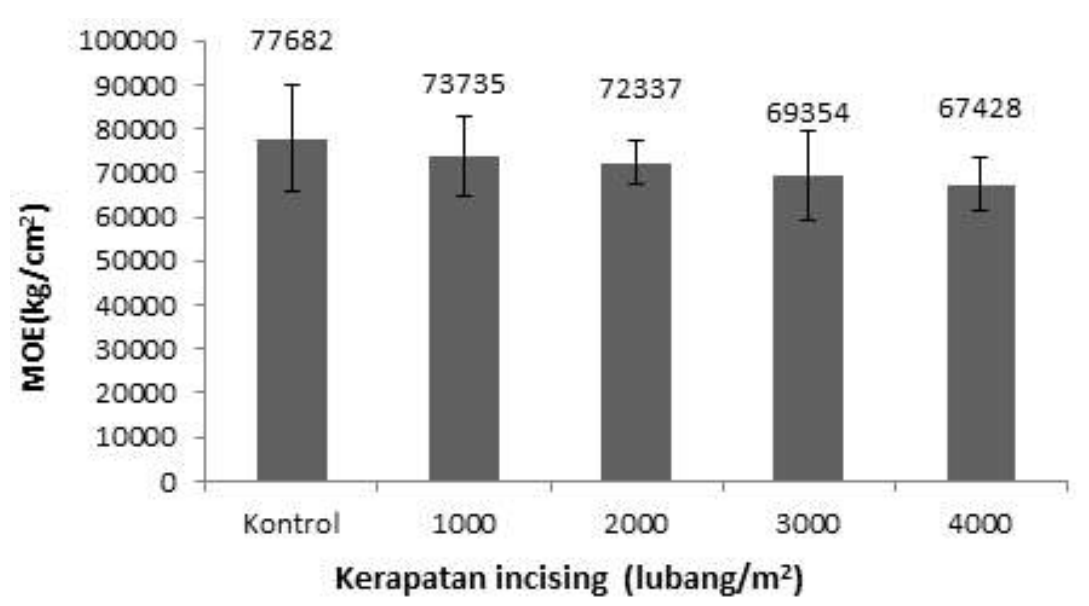

Gambar 9. Nilai modulus elastistas (MoE) kayu mahoni pada berbagai variasi kerapatan incising.

Martawijaya et al. (2005) dimana MoE sebesar $92.000 \mathrm{~kg} / \mathrm{cm}^{2}$.

Hasil analisis varian terhadap nilai MoR dan MoE menunjukkan bahwa tidak ada perbedaan antara sampel yang tidak diperlakukan incising dan sampel yang diperlakukan incising pada 4 variasinya $(0$, 1000, 2000, 3000, dan 4000 lubang/m²). Hal ini menunjukkan bahwa walaupun terjadi penurunan MoR dan MoE, tetapi secara statistik masih sama dengan sampel bukan incising. Mempertimbangkan hasil tersebut maka perlakuan incising masih diperbolehkan dengan batas 4000 lubang/ $\mathrm{m}^{2}$. Dengan demikian, pra perlakuan incising ini dapat diterapkan untuk mempercepat proses pengeringan dengan penurunan keteguhan lengkung statik yang tidak nyata.

\section{KESIMPULAN}

Perlakuan incising dengan sistem bor dengan kerapatan incising 3000-4000 lubang $/ \mathrm{m}^{2}$ berpengaruh nyata pada kecepatan pengeringan. Gradien distribusi kadar akhir juga menunjukkan indikasi positif pada perlakuan incising 3000 dan 4000 lubang $/ \mathrm{m}^{2}$. Pra perlakuan incising sampai batas 4000 lubang $/ \mathrm{m}^{2}$ ini dapat diterapkan untuk mempercepat proses pengeringan dengan penurunan MoR dan MoE yang tidak berbeda nyata.

\section{DAFTAR PUSTAKA}

BS 373. 1957 Methods of testing small clear specimens of timber. British Standards Institution, London, UK. 32 .

Cech MY \& Huffman DR. 1971. High temperature kiln drying of spruce joist. Forest Product Journal 21(10), 55-60.

Chudnoff M. 1972. Void volume wood: an any tree-whole tree use concept. Forest Product Journal 22(6), 49-53.

Erickson R \& Demaree L. 1972. The drying of predrilled aspen lumber. Forest Product Journal 22, 48-50.

Fruhwald E. 2007. Effect of high-temperature drying on properties of Norway spruce and larch. Holz als Roh-und Werkstoff 65, 411-418.

Gerhards CC. 1979. Effect of high temperature drying on tensile strength of Douglas-fir 2 by 4's. Forest Product Journal 29(3), 39-46.

Hattori N, Ando K, Kitayama S, Kubo T, \& Kobayashi Y. 1997. Application of laser incising to microwave drying of sugi square lumber with black-heart. Forest Resource Environment 35, 53-60.

Kollmann FFP. 1961. High temperature drying: research, application, and experience in Germany. Forest Product Journal 11(11), 508-515. 
Langrish T \& Walker JCF. 2006. Drying of Timber. Dalam : Wood Primary Processing. Walker, JCF (Ed.). Springer, Dordrecht.

Listyanto T, Ando K, Yamauchi H, \& Hattori N. 2013. Microwave and steam injection drying of $\mathrm{CO}_{2}$ laser incised Sugi Lumber. Journal of Wood Science 59(4), 282-289.

Lee NH, Li C, Zhao XF, \& Park MJ. 2010. Effect of pretreatment with high temperature and low humidity on drying time and prevention of checking during radio-frequency/vacuum drying of Japanese cedar pillar. Journal of Wood Science 56(1), 19-24.

Martawijaya A, Kartasudjana I, Mandang Y, Prawira SA, \& Kadir K. 2005. Atlas Kayu Indonesia Jilid I. Departemen Kehutanan, Badan Penelitian dan Pengembangan Kehutanan. Bogor.

Obataya E, Shibutani S, Hanata K, \& Doi S. 2006. Effect of high temperature kiln drying on practical performance of japan cedar wood (Cryptomeria japonica) I : changes in hygroscopicity due to heating. Journal of Wood Science 52, 33-38.

Palmer JR. 1994. Designing commercially promising tropical timber species. Dalam : Tropical Trees: The Potential for Domestication and the Rebuilding of Forest Resources. Leakey RRB dan Newton AC (Eds). Proceedings of a Conference organized by the Edinburgh Centre for Tropical Forests; 1992 August 23-28; HMSO, London: Heriot-Watt University. 16-24.

Pandey D \& Brown C. 2000. Teak: a global review. Unasylva 51(201), 3-13.

Rhatigan RG, Milota MR, Morrel JJ, \& Lavery MR. 2003. Effect of high temperature drying on permeability and treatment of western hemlock lumber. Forest Products Journal 53(9), 55-58.

Rosen HN, Bodkin RE, \& Gaddis KD. 1983. Pressure steam drying of lumber. Forest Product Journal 33(1), 17-24.

Sehlstedt-Persson SMB. 1995. High-temperature drying of Scots pine: a comparison between HTand LT-drying. Holz als Roh-und Werkstoff 53, 95-99.

Siau JF. 1984. Transport Processes in Wood. Springer-Verlag, Berlin. 245.

Simpson WT. 1987. Laser incising to increase drying rate of wood. Wood and Fiber Science 19(1), 9-24.

Skaar C. 1988. Wood-water Relations. Springer-Verlag, Berlin, Heidelberg. 279 .
Stamm AJ \& Raleigh NC. 1967. Movement of fluids in wood. Part I: flow fluids in wood. Wood Science and Technology 1, 122-141

Winandy JE \& Morrell JJ. 1998. Effects of incising on lumber strength and stiffness: relationships between incision density and depth, species and MSR grade. Wood and Fiber Science 30(2), 185-197. 